\title{
Cocaine-Specific Effects on Exosome Biogenesis in Microglial Cells
}

\author{
Sanjay Kumar ${ }^{1}$ Brennetta J. Crenshaw ${ }^{2}$. Sparkle D. Williams ${ }^{1} \cdot$ Courtnee' R. Bell $^{2}$ - Qiana L. Matthews ${ }^{2} \cdot$ Brian Sims $^{1}$
}

Received: 26 May 2020 / Revised: 18 November 2020 / Accepted: 4 January 2021 / Published online: 8 February 2021

(c) The Author(s) 2021

\begin{abstract}
Cocaine is a highly addictive stimulant and a well-known drug, with multiple effects on physiology. Cocaine can have direct effects on all cell types in the brain, including microglia. Microglia can be activated by other conditions, such as infection, inflammation, or injury. However, how cocaine regulates microglia and the influence of cocaine on microglial-derived exosomes remains unknown. Exosomes are nanovesicles that are responsible for intercellular communications, signaling, and trafficking necessary cargo for cell homeostasis. In this study, we hypothesized that cocaine affects exosome biogenesis and composition in BV2 microglial cells. BV2 microglial cells were cultured in exosome-depleted RPMI-1640 media and were treated according to the experimental designs. We observed that cell viability decreased by $11 \%$ at $100 \mu \mathrm{M}$ cocaine treatment but was unaffected at other concentrations. After treatments, the exosomes were isolated from the condition media. Purified exosomes were characterized and quantified using transmission electron microscope (TEM) and nanoparticle tracking analysis (NTA). By NTA, there was a significant decrease in particles $/ \mathrm{mL}$ after cocaine treatment. There was a $39.5 \%, 58.1 \%$, $32.3 \%$ and $28.1 \%$ decrease in particles $/ \mathrm{mL}$ at $100 \mathrm{nM}, 1 \mu \mathrm{M}, 10 \mu \mathrm{M}$ and $100 \mu \mathrm{M}$ cocaine, respectively. The characterization of exosomes and exosomal protein was performed by western/dot blot analyses. Tetraspanins CD11b, CD18 and CD63 were relatively unchanged after cocaine treatment. The heat shock proteins (Hsps), Hsp70 and Hsp90, were both significantly increased at $10 \mu \mathrm{M}$ and $100 \mu \mathrm{M}$, but only hsp70 was significantly increased at $10 \mathrm{nM}$. The Rab proteins were assessed to investigate their role in cocaine-mediated exosomal decrease. Rab11 was significantly decreased at $10 \mathrm{nM}, 100 \mathrm{nM}, 1 \mu \mathrm{M}$, $10 \mu \mathrm{M}$ and $100 \mu \mathrm{M}$ by $15 \%, 28 \%, 25 \%, 38 \%$ and $22 \%$, respectively. Rab27 was decreased at all concentrations but only significantly decreased at $100 \mathrm{nM}, 1 \mu \mathrm{M}$ and $100 \mu \mathrm{M}$ cocaine by $21 \%, 24 \%$ and $23 \%$, respectively. Rab35 had no significant changes noted when compared to control. Rab7 increased at all cocaine concentrations but only a significant increase in expression at $100 \mathrm{nM}$ and $10 \mu \mathrm{M}$ by 1.32-fold and 1.4-fold increase. Cocaine was found to alter exosome biogenesis and composition in BV2 microglial cells. Western and dot blot analyses verified the identities of purified exosomes, and the specific protein compositions of exosomes were found to change in the presence of cocaine. Furthermore, cocaine exposure modulated the expression of exosomal proteins, such as Hsps and Rab GTPases, suggesting the protein composition and formation of microglial-derived exosomes were regulated by cocaine.
\end{abstract}

Keywords Cocaine $\cdot$ Exosomes $\cdot \mathrm{BV} 2$ microglia $\cdot$ Heat shock proteins $\cdot$ Lipids $\cdot$ rab GTPases

\author{
Brian Sims \\ bsims@peds.uab.edu \\ Sanjay Kumar \\ skumar@peds.uab.edu \\ Brennetta J. Crenshaw \\ Bjcrenshaw0320@gmail.com \\ Sparkle D. Williams \\ swilliams@vt.edu \\ Courtnee' R. Bell \\ courtneerbell@yahoo.com \\ Qiana L. Matthews \\ qmatthews@alasu.edu
}

1 Department of Pediatrics/Division of Neonatology and Center of Glial Biology in Medicine at the University of Alabama School of Medicine, UAB Women and Infant Center, University of Alabama, 1700 6th Ave South, Birmingham, AL 35294, USA

2 Microbiology Program, Department of Biological Sciences, College of Science, Technology, Engineering and Mathematics, Alabama State University, Montgomery, AL 36104, USA 


\section{Introduction}

Microglia are considered to be the most potent immune cells in the central nervous system (CNS) [1]. Microglia are activated during stress, inflammation, infections, and conditions that result in cellular damage, leading to the phagocytosis of damaged cells and the secretion of various cytokines [1-3]. Microglia survey and monitor the brain for harmful substances and pathogenic agents such as bacteria [1-3]. Upon activation, these cells transform from a 'resting state' to an 'active state' [3], during which microglia undergo changes in mobility and cellular morphology. Glial cell activation leads to the expression of specific receptors on their surfaces $[4,5]$. In the 'active state', microglial cells release cytokines and demonstrate enhanced phagocytic functions [4, 5]. Microglia, like other cells, utilize exosomes for intercellular communications [6-8]. It is unclear if exosome biogenesis changes when microglia are activated.

Exosomes are unique structures that contain multiple proteins, lipids, microRNA, and RNA molecules [6-15]. They are usually $30-150 \mathrm{~nm}$ in diameter and express specific proteins such as alix, tetraspanins, integrins, Tsg101, heat shock proteins (Hsps), and Rab GTPases [6-15]. Exosomal membranes are enriched in specific lipid compounds, such as sphingomyelin, phosphatidylserine, phosphocholine, and cholesterol [12-20]. Exosomes have also demonstrated the ability to regulate cell waste by acting as cargo vessels [21]. Exosomes originate from multivesicular bodies (MVBs), through the inward budding of endosomal membranes, and are released when MVBs fuse with the plasma membrane. All body fluids (such as breastmilk, urine, blood, and plasma) have been shown to contain exosomes; however, their specific roles in different parts of the body remain unclear.

The regulation of exosome secretion by microglial cells is not well-understood; however, some studies have suggested that cytokines are involved in the regulation of exosome secretion and formation. Drugs of abuse, such as cocaine, have been shown to cross the blood-brain barrier and be a potent activator of microglia [22]. Several studies have demonstrated that F-actin is disrupted in endothelial cells and a concomitant decrease in expression of tight junction proteins leading to weakening of the blood-brain barrier [23-26]. Cocaine is one of the most used illicit drugs in the United States. Cocaine abuse results in a variety of CNS disorders, including an increased risk of stroke, seizures, cognitive impairment, depression, and, in extreme cases, death [27, 28]. Studies have demonstrated that cocaine administration can enhance the expression of cytokines/chemokines and adhesion molecules, through the binding of cocaine with its cognate receptor, which are expressed on a variety of cells [22, 29, 30], and these changes could result in altered exosomal production.

Studies have demonstrated cocaine-specific effects on microglial activation such as the release of brain-derived neurotrophic factor, other growth factors, and associated regulation of microRNA [22, 29, 30]; however, the effects of cocaine on exosome biogenesis and composition have not been studied. Therefore, in the present investigation, we aimed to test the effects of cocaine on the biogenesis and composition of BV2 microglial-derived exosomes. This investigation is the first of its sort and could help improve our comprehension of exosomal biology.

\section{Materials and Methods}

\section{Cell Culture and Cocaine Exposure}

Microglial (BV2) cells were grown in complete medium (Roswell Memorial Park Institute-1640 (RPMI-1640) medium (Fisher Scientific, Hampton, NH, USA), supplemented with $10 \%$ fetal bovine serum (FBS), containing $1 \mathrm{X}$ L-glutamine, $1 \%$ penicillin/streptomycin, and $0.05 \%$ Amphotericin-B (Fisher Scientific, Hampton, NH, USA), at $37{ }^{\circ} \mathrm{C}$, in a $5 \% \mathrm{CO}_{2}$ atmosphere. These cells were a generous gift from Dr. Harald Neumann at the University of Bonn LIFE and Brain Center in Bonn, Germany [31]. BV2 microglial cells were plated at a density of $2 \times 10^{6}$ cells/ dish and allowed to acclimatized overnight before cocaine (Sigma, St. Louis, MO, USA) treatments. The medium from each dish was removed and replaced with either exosomefree RPMI-1640 media only (control treatment) or exosomefree RPMI-1640 media containing $10 \mathrm{nM}, 100 \mathrm{nM}, 1 \mu \mathrm{M}$, $10 \mu \mathrm{M}$, or $100 \mu \mathrm{M}$ cocaine for $24 \mathrm{~h}$. All experiments were performed using 3-5 independent experiments.

\section{Trypan Blue Exclusion}

To test cell viability, the trypan blue exclusion method was utilized. BV2 cells were harvested and centrifuged at 500 revolutions per $\min (\mathrm{rpm})$, for $5 \mathrm{~min}$, at $4{ }^{\circ} \mathrm{C}$. The supernatant was discarded, the cell pellet was resuspended in $1 \mathrm{~mL}$ complete medium, and $10 \mu \mathrm{L}$ resuspended pellet was mixed with $10 \mu \mathrm{L}$ trypan blue dye (Fisher Scientific, Hampton, NH, USA). After gentle mixing, $10 \mu \mathrm{L}$ of the cells mixed with trypan blue were loaded into a hemocytometer to perform a live/dead cell count. The resulting values were plotted on a graph to examine differences in the numbers of live and 
dead cells among the treatment groups. Viable cells were calculated using the following formula:
Tecnai $120 \mathrm{kV}$ (FEI, Hillsboro, OR) at $80 \mathrm{kV}$ within $24 \mathrm{~h}$ as compared to the negatively stained grids. Digital images

Viable cells $=[1.00-($ Number of blue cells $\div$ Number of total cells $)] \times 100$

\section{Microscopic Examination}

To assess the cell morphology, microglial cells were exposed to $10 \mathrm{nM}, 100 \mathrm{nM}, 1 \mu \mathrm{M}, 10 \mu \mathrm{M}$, and $100 \mu \mathrm{M}$ cocaine for $24 \mathrm{~h}$. After $24 \mathrm{~h}$, the morphologies of the microglial cells were examined at $\times 10$ magnification using an Invitrogen EVOS TM FL system ${ }^{\mathrm{TM}}$ (ThermoFisher Scientific, Waltham, MA, USA).

\section{Ultracentrifugation}

To isolate and purify exosomes from cocaine-treated microglia, the media was carefully collected and centrifuged at $1300 \mathrm{rpm}$ at $4{ }^{\circ} \mathrm{C}$ for $10 \mathrm{~min}$, using a Sorvall 6000 refrigerated centrifuge (Sorvall. Ontario, Canada). The pellet was discarded, and the supernatant was centrifuged again at $39,000 \mathrm{rpm}$, at $4{ }^{\circ} \mathrm{C}$ for $10 \mathrm{~min}$, and the resulting supernatant was filtered through a $0.22 \mu \mathrm{M}$ filter and collected in ultracentrifuge tubes. The samples were then centrifuged at $10,800 \mathrm{rpm}$ at $4{ }^{\circ} \mathrm{C}$ for $45 \mathrm{~min}$, in an SW41T1 swinging bucket rotor, using a Beckmann Coulter Optima L-70 K Ultracentrifuge Beckman Counter, IN, USA. The exosome fraction was collected by the ultracentrifugation of the resulting supernatant at 32,000 rpm, in an SW41T1 swinging bucket rotor, for $70 \mathrm{~min}$ at $4{ }^{\circ} \mathrm{C}$. The total protein levels in the exosome fraction were quantified using the Lowry protein quantification method.

\section{Transmission Electron Microscopy (TEM)}

Exosomes were produced by incubating BV2 cells in exosome depleted-medium containing $10 \mathrm{nM}, 100 \mathrm{nM}, 1 \mu \mathrm{M}$, $10 \mu \mathrm{M}$, or $100 \mu \mathrm{M}$ of cocaine and without cocaine (control) for $24 \mathrm{~h}$. Freshly isolated BV2-derived exosomes were resuspended in PBS and diluted in 1:1 with 5\% glutaraldehyde. Before loading sample on the EM-grids, carbon film coated mesh copper EM-grid were glow discharge at $50 \mathrm{~mA}$ for $20 \mathrm{~s}$; thereafter, $7 \mu \mathrm{L}$ exosomes suspension solution was loaded on the grid and incubated for $1 \mathrm{~min}$ at RT. Wick excess with a torn edge of a Whatman filter paper by wicking from below the grid was done in order to pull the sample towards the grid rather than away from it. Samples were immediately stained with $7 \mu \mathrm{L}$ of filtered Uranyl acetate (UA) solution on the surface of the EM-grid. After $15 \mathrm{~s}$ excess UA solution was removed and samples were observed under transmission electron microscope (TEM) were captured with a BioSprint 29 CCD Camera (AMT, Woburn, MA).

\section{Nanoparticle Tracking Analysis}

To assess the sizes and numbers of exosome particles per $\mathrm{mL}$ solution, nanoparticle tracking analysis (NTA) was performed, using a NanoSight-LM10 (Malvern Instrument, Inc., Malvern, UK). The samples were diluted in $1 \times$ phosphate buffer saline (PBS) and loaded into a $0.3 \mathrm{~mL}$ disposable syringe. The NTA analyzes samples based on the principle of Brownian particle movement. The mean values for five independent experiments were recorded and processed for each reading frame.

\section{Western and Dot Blot Analysis}

To examine the expression of tetraspanin, adhesion molecules, Hsps, and Rab GTPases, western and dot blot analyses were performed, using $60 \mu \mathrm{g} / \mathrm{well}$ for western blot and $5 \mu \mathrm{g}$ total protein per dot, after boiling at $99{ }^{\circ} \mathrm{C}$ for $5 \mathrm{~min}$. Proteins were transferred onto PVDF membranes at $15 \mathrm{~V}$ for $1 \mathrm{~h}$ and for dot blot membranes were allowed to dry for 5-10 min, then blocked with Pierce Fast Blocker, containing $0.09 \%$ Tween-20 for 5-15 min at room temperature (RT) on a shaker. Then, membranes were hybridized with the following primary antibodies against tetraspanin and membrane molecules, for $1 \mathrm{~h}$, at RT: Cluster of differentiation (CD)11b (0.1 $\mu \mathrm{g} / \mathrm{mL})$, CD18 (1:500), CD63 (0.5 $\mu \mathrm{g} /$ $\mathrm{mL})$, Calnexin (1:5000), Hsp70 (1:1,000), Hsp90 (1:1000), $\operatorname{Rab} 7(1 \mu \mathrm{g} / \mathrm{mL}), \operatorname{Rab} 11,(0.5 \mu \mathrm{g} / \mathrm{mL}), \operatorname{Rab} 27 \mathrm{~A}(0.5 \mu \mathrm{g} / \mathrm{mL})$, and Rab35 (1:750) (all from Fisher Scientific, Hampton, NH, USA). Membranes were washed with $1 \times$ Tris-buffersaline (TBS) buffer, containing 0.09\% Tween-20 (TBST$20)$, for $3 \mathrm{x}-10 \mathrm{~min}$ each wash. The appropriate horseradish peroxidase-conjugated secondary antibodies (Fisher Scientific, Hampton, NH, USA), goat anti-rabbit (1:1000), goat anti-mouse $(11,000)$, or goat anti-hamster (1:5000), were incubated with the membranes in 1-2\% non-fat milk solution in TBST-20 buffer for $1 \mathrm{~h}$ at RT. Membranes were washed three times with TBST-20, for 10 min per wash, and developed using an Invitrogen Novex ECL chemiluminescence liquid substrate kit (ThermoFisher Scientific, Waltham, MA, USA). The signals were detected on X-ray and a Bio-Rad ChemiDoc XRS ${ }^{+}$system (BioRad, Hercules, CA, USA). 


\section{Lipid Assay}

Total lipid, total cholesterol, phospholipid, sphingolipid, phosphatidylcholine (Cell BioLabs, Inc., San Diego, CA, USA), and phosphatidylserine (BioVision, Milpitas, CA, USA) and levels were determined in the exosome fractions using a fluorometric assay. For each assay, $30 \mu \mathrm{g}$ isolated exosome fraction from control or cocaine-treated samples was added to each well, in duplicate, using $n=3-5$ of standard, lipid cholesterol, phospholipid, sphingolipid, phosphatidylserine, and phosphatidylcholine. To each well, $100 \mu \mathrm{L}$ of the reaction reagent was added, and the well contents were mixed thoroughly. The plates were covered, protected from light, and incubated for $45-60 \mathrm{~min}$ at $37^{\circ} \mathrm{C}$, then read with a fluorescence microplate reader equipped for excitations in the 530-570 $\mathrm{nm}$ range and for emissions in the $590-600 \mathrm{~nm}$ range.

\section{Statistical Analysis}

Statistical analyses were performed using one-way analysis of variance (ANOVA) with Tukey post hoc analysis. Statistical significance is indicated by the mean $\pm \mathrm{SD}$ as follows: $\mathrm{p}<0.05(*) ; \mathrm{p}<0.01(* *) ; \mathrm{p}<0.001(* * *)$; and $\mathrm{p}<0.0001(* * * *)$.

\section{Results}

\section{Cocaine Exposure Reduced BV2 Cell Viability}

To test the direct effects of cocaine on cellular viability, cells were treated with cocaine $(10 \mathrm{nM}, 100 \mathrm{nM}, 1 \mu \mathrm{M}, 10 \mu \mathrm{M}$, and $100 \mu \mathrm{M}$ ) and then assessed for cell morphology, under an inverted light microscope, and cell viability, using a

Total lipid component $=\left[\frac{\text { sample corrected fluorescence }}{\text { slope }}\right]$ sample dilution

A
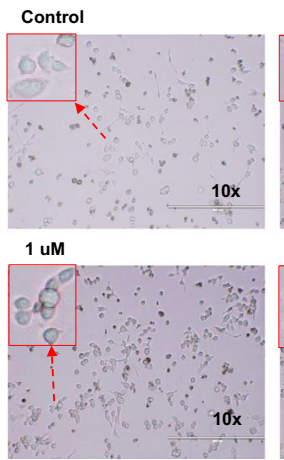

$10 \mathrm{nM}$

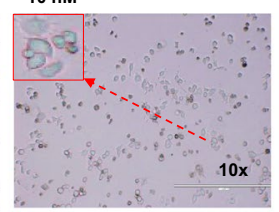

$10 \mathrm{uM}$

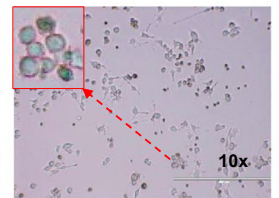

B

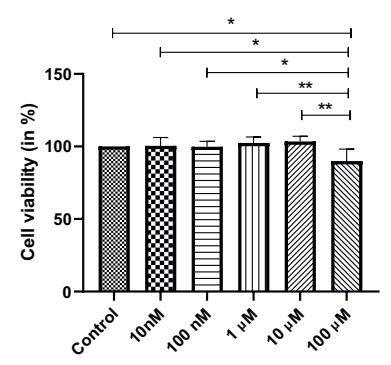

Fig. 1 Cocaine-specific effects on BV2 microglial cell viability and the mean size and number of particles. BV2 microglial cells were treated with $10 \mathrm{nM}, 100 \mathrm{nM}, 1 \mu \mathrm{M}, 10 \mu \mathrm{M}$, and $100 \mu \mathrm{M}$ cocaine. Cells were grown in exosome-free medium and the cocaine was added for a maximum of $24 \mathrm{~h}$. a Microscopy, b cell viability, c

$100 \mathrm{uM}$
C
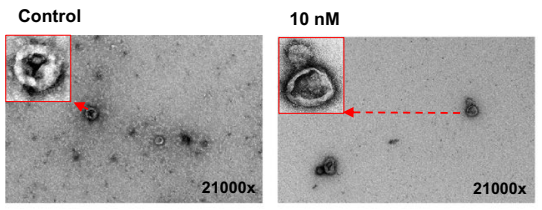

$100 \mathrm{nM}$
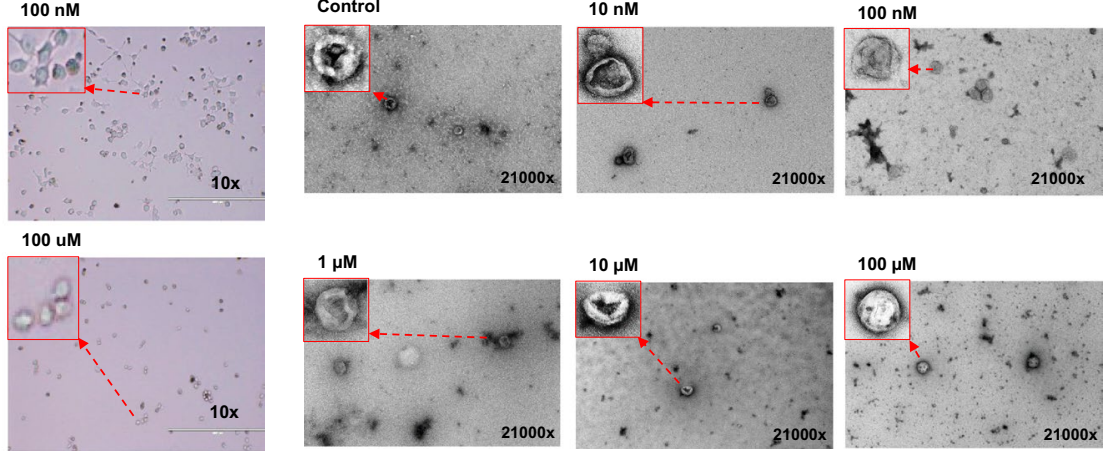

D

$\mathbf{E}$
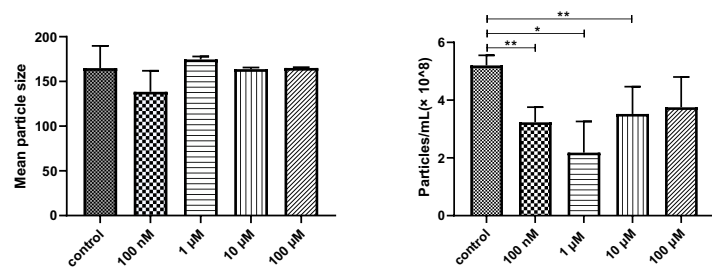

TEM, $\mathbf{d}$ mean particle size and e particle/mL. Mean size is shown in nanometers, and particle numbers are shown as $10^{8}$ per mL. Statistical significance is taken from 3 to 5 independent experiment in triplicates and indicated the mean of SD as follows: $* \mathrm{p}<0.05$; $* * \mathrm{p}<0.001 ;$ and $* * * \mathrm{p}<0.0001$ 
trypan blue exclusion method, as previously described [32-34]. Our findings demonstrated that control cells (Fig. 1a) showed robust growth, as indicated by the cell culture surface at $24 \mathrm{~h}$, whereas exposure to $100 \mu \mathrm{M}$ cocaine caused morphological alterations, resulting in a more complete rounding of the cells (Fig. 1a). To further validate these findings, BV2 cell viability was assessed using the trypan blue exclusion method $24 \mathrm{~h}$ after cocaine was added, which was the duration of the experiment. Our findings suggested that cells treated with $100 \mu \mathrm{M}$ cocaine showed reduced cell viability by $11 \%$ when compared with control cells and other experimental groups, such as the $10 \mathrm{nM}, 100 \mathrm{nM}, 1 \mu \mathrm{M}$, and $10 \mu \mathrm{M}$ cocaine treatment groups $(* \mathrm{p}<0.05$ and $* * \mathrm{p}<0.01)$ (Fig. 1b). These findings suggested that BV2 cell viability was affected at the highest cocaine concentration examined in this study (Fig. 1a and b; all individual data points can be observed in supplemental Figs. 1-5).

\section{Effects of Cocaine on Exosome Characteristics}

Previous studies have demonstrated that almost all cell types, including bacteria, produce nanosized vesicles known as exosomes $[35,36]$. Exosomes play important roles in cellto-cell communication and signaling and can act as cargo vesicles, and altering these functions could have critical implications for cells. Therefore, we tested the effects of cocaine treatments on the mean size and particle numbers of exosomes per $\mathrm{mL}$. BV2 cell-derived exosomes were purified, using ultracentrifugation, and the purified exosomes were evaluated for size using TEM and NTA (Fig. 1c and d), and the number of exosome particles per $\mathrm{mL}$ was also determined by NTA (Fig. 1e). Our findings suggested that the mean size was not affected by cocaine administration. Control mean size $(164.83 \pm 24.93 \mathrm{~nm})$ was compared to $100 \mathrm{nM}(138.37 \pm 40.70 \mathrm{~nm}), 1 \mu \mathrm{M}(174.64 \pm 7.19 \mathrm{~nm})$, $10 \mu \mathrm{M}(163.74 \pm 4.15 \mathrm{~nm})$ and $100 \mu \mathrm{M}(165.04 \pm 1.77 \mathrm{~nm})$
A

(i)

(ii)

(iii)

(iv)

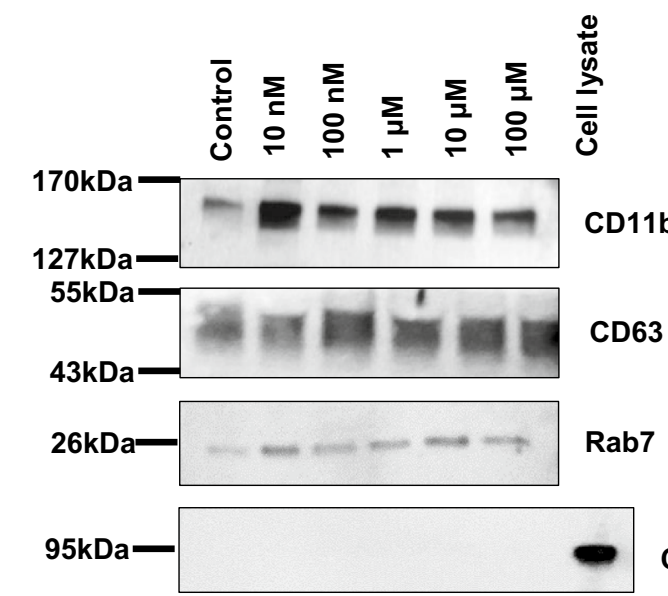

B

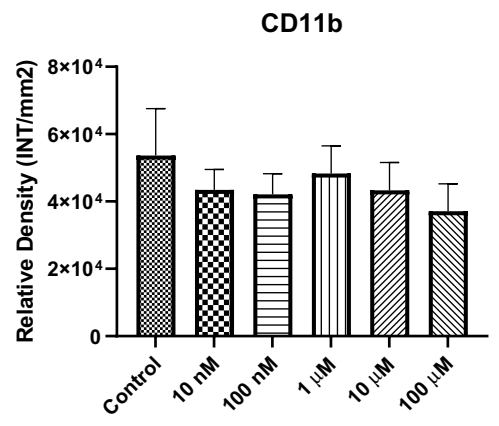

Fig. 2 Cocaine-specific effects on cell membrane molecules. BV2 microglial cells were treated with cocaine $(10 \mathrm{nM}, 100 \mathrm{nM}, 1 \mu \mathrm{M}$, $10 \mu \mathrm{M}$, and $100 \mu \mathrm{M})$ for $24 \mathrm{~h}$, and the expression of cell membrane molecules in exosomes was determined using western and dot blot analysis. a representative western blots; (i) CD11b, (ii) CD63, (iii)

\section{C}

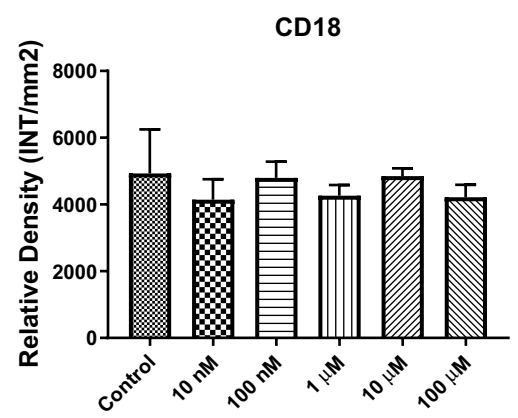

D

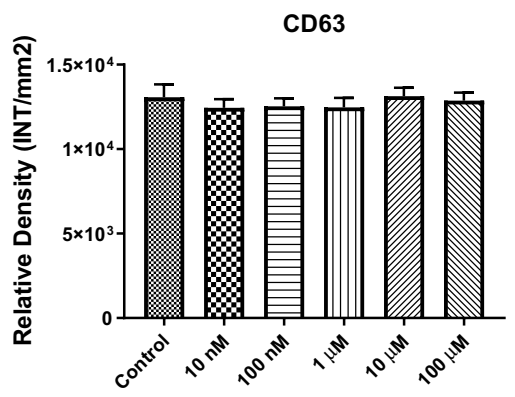

Rab7 and (iv) Calnexin, b CD11b expression, c CD18 expression and d CD63 expression. Statistical significance is taken from 5 independent experiment in triplicates and indicated the mean of SD as follows: $* \mathrm{p}<0.05 ;$ and $* * \mathrm{p}<0.001$ 
and no significant changes noted. However, the particle numbers per $\mathrm{mL}$ were significantly reduced after treatment comparing control $\left(5.20 \pm 0.35^{*} 10^{8}\right.$ particles $\left./ \mathrm{mL}\right)$ by $39.5 \%$ at $100 \mathrm{nM}\left(3.23 \pm 0.53 * 10^{8}\right.$ particles $\left./ \mathrm{mL}\right)$, by $58.1 \%$ at $1 \mu \mathrm{M}\left(2.18 \pm 1.08 * 10^{8}\right.$ particles $\left./ \mathrm{mL}\right)$, by $32.3 \%$ at $10 \mu \mathrm{M}$ $\left(3.52 \pm 0.95^{*} 10^{8}\right.$ particles $\left./ \mathrm{mL}\right)$ and by $28.1 \%$ at $100 \mu \mathrm{M}$ $\left(3.75 \pm 1.05 * 10^{8}\right.$ particles $/ \mathrm{mL}$ ) of cocaine (Fig. 1e). Treatment with $100 \mu \mathrm{M}$ cocaine did not result in a significant difference compared with the control (Fig. 1e).

\section{Cocaine-Specific Effects on Cell Membrane Proteins in Exosomes}

The cell membrane is composed of several types of proteins, which act as a barrier and a communication platform, connecting the outside world to the intracellular control centers. Clusters of differentiation proteins, such as CD63 and CD81, are tetraspanin molecules that interact with a variety of cell surface proteins and intracellular molecules, inducing processes that include adhesion, motility, membrane organization, and signal transduction [37-41]. The transmembrane proteins CD11b (a surface marker for microglia, monocytes, and macrophages) and CD18 play critical roles in cellular adhesion [42]. Calnexin protein should only be in the cell but not in the exosomes. To examine the expression of these proteins following cocaine treatment, western/dot blot analyses of exosomal protein was performed. As it was shown in a representative Fig. 2a(i) expression of CD11b, 2A (ii) expression of CD63, 2A (iii) expression of Rab7, and 2A(iv) expression of Calnexin. We found that CD11b (Fig. 2b), CD18 (Fig. 2c), and CD63 (Fig. 2d) showed slightly decreased expression in exosomes after cocaine treatment; however, these changes were not significant when

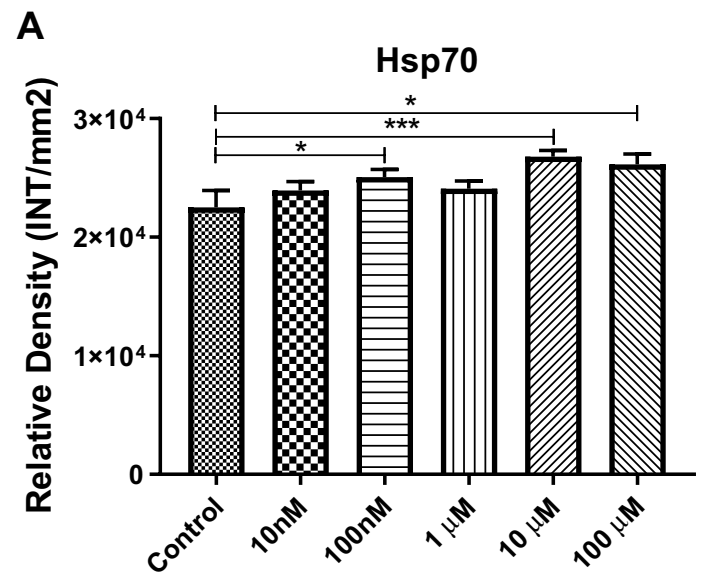

Fig. 3 Cocaine-specific effects on Hsps in BV2 cells and exosomes. BV2 microglial cells were treated with cocaine $(10 \mathrm{nM}, 100 \mathrm{nM}$, $1 \mu \mathrm{M}, 10 \mu \mathrm{M}$, and $100 \mu \mathrm{M}$ ) for $24 \mathrm{~h}$, and the expression levels of was evaluated in in exosomes. a Hsp70 and b Hsp90 densities derived compared with the control. Furthermore, BV2 cell-derived exosomes showed low expression of CD81 (data not shown).

\section{Cocaine-Specific Effects on Hsp Expression in Exosomes}

Hsps, or stress proteins, are members of a highly conserved group of proteins found in all eukaryotes and prokaryotes, including bacteria. They act as molecular chaperones, assisting the proper folding/refolding of newly synthesized proteins $[43,44]$. In addition, they play cytoprotective roles under stress and trauma conditions, and their expression levels increase many-fold when cells are exposed to drugs, heavy metals, and heat [43, 44]. HSPs can be found in exosomes; therefore, in the current investigation, the expression of $\mathrm{Hsp} 70$ and $\mathrm{Hsp} 90$ were evaluated using dot blot analysis. Our results indicated that exosomal Hsp70 expression were significantly increased after treatment with $100 \mathrm{nM}$ (1.11 fold increase, $\mathrm{p} \leq 0.05), 10 \mu \mathrm{M}$ (1.19 fold increase, $p \leq 0.0001)$, and $100 \mu \mathrm{M}$ (1.16 fold increase, $\mathrm{p} \leq 0.05$ ) cocaine compared with control (Fig. $3 \mathrm{~A}$ ), whereas Hsp90 (Fig. 3B) showed statistically significant increases in its expression after treatment with $10 \mu \mathrm{M}(1.17$ fold increase, $\mathrm{p} \leq 0.0001)$ and $100 \mu \mathrm{M}(1.22$ fold increase, $\mathrm{p} \leq 0.0001)$ cocaine when compared with the control (Fig. 3A and B), suggesting that Hsps are regulated by cocaine administration.

\section{Cocaine Modulates Rab GTPases in Exosomes}

In this study, we showed that cocaine exposure altered the number of exosome particles per $\mathrm{mL}$. To test whether this reduction in exosomal numbers was associated with Rab GTPases, we examined the expression levels of Rab7,

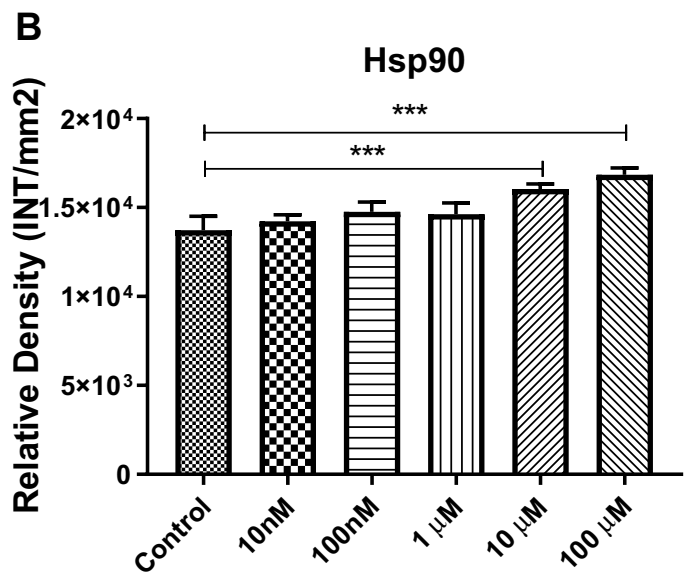

from dot blot. Statistical significance derived from 5 independent experiment in triplicates is indicated the mean of SD as follows: $* \mathrm{p}<0.05 ; * * \mathrm{p}<0.001 ;$ and $* * * \mathrm{p}<0.0001$ 

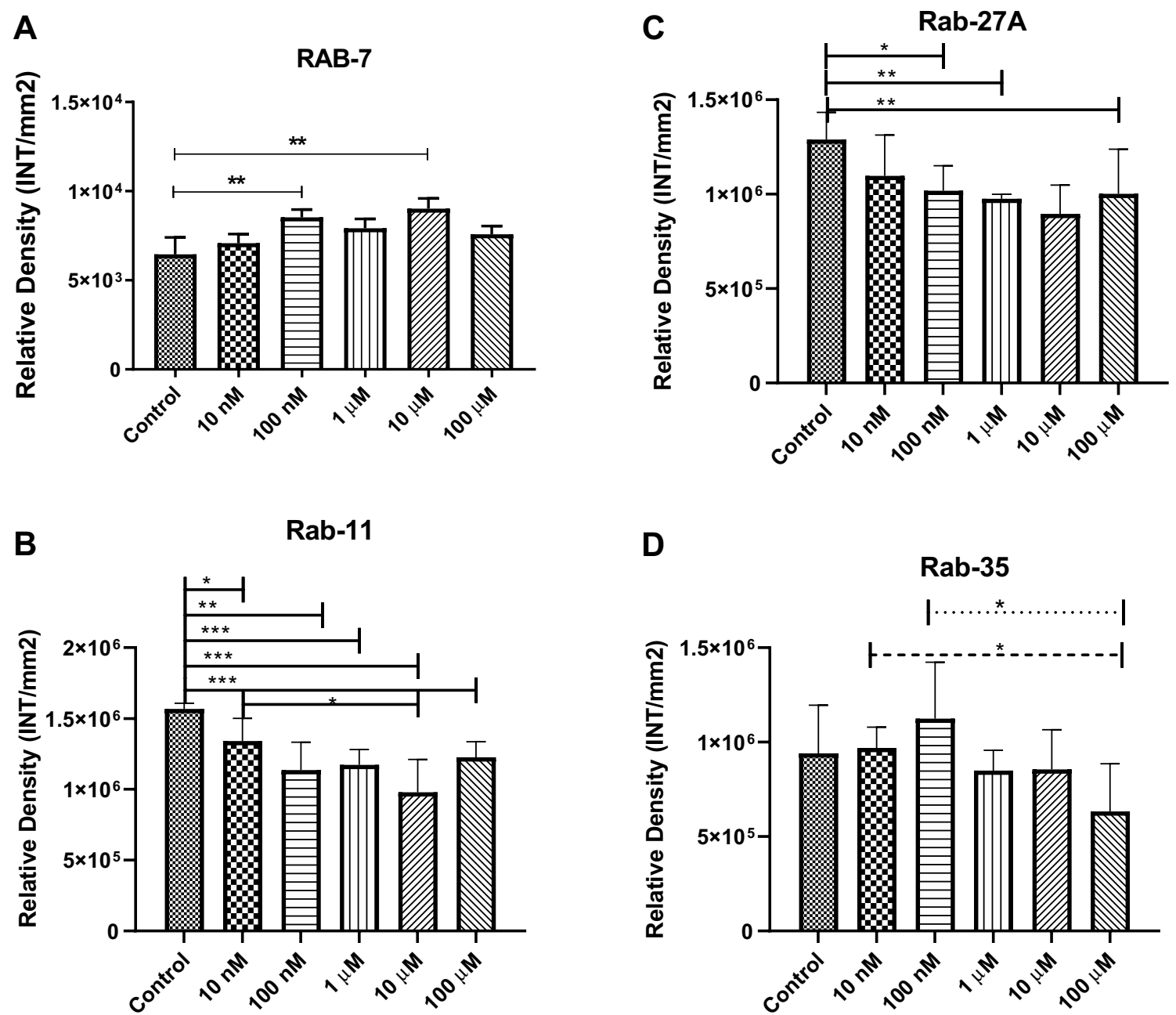

Fig. 4 Cocaine-specific effects on Rab GTPases. To examine the expression of Rab GTPases in microglial cells, cells were incubated with $10 \mathrm{nM}, 100 \mathrm{nM}, 1 \mu \mathrm{M}, 10 \mu \mathrm{M}$, and $100 \mu \mathrm{M}$ cocaine for $24 \mathrm{~h}$, and Rab protein expression levels were evaluated in BV2 cells and exosomes using dot blot analysis. a Rab7, b Rab11, c Rab27A and

d Rab35 expression in BV2 cell-derived exosomes. Statistical significance derived from 5 independent experiment in triplicates is indicated the mean of SD as follows: $* \mathrm{p}<0.05$; $* * \mathrm{p}<0.001$; and $* * * \mathrm{p}<0.0001$

Rab11, Rab27A, and Rab35 in BV2 cells and exosomes. Rab proteins belong to the Ras superfamily of small Rab GTPases [45]. Rab5 and Rab7 are present in the plasma membrane and early endosomes, and regulate vesicular trafficking during early endocytosis, whereas Rab11, Rab27A, and Rab35 are associated with protein sorting, secretion, and targeting [45-47]. Therefore, Rab proteins represent significant components of exosome biogenesis, sorting, and secretion machinery. Our experimental findings showed that Rab7 expression in exosomes increased after exposure to $100 \mathrm{nM}$ (1.32 fold increase, $\mathrm{p} \leq 0.001)$, and $10 \mu \mathrm{M}(1.40$ fold increase, $p \leq 0.001$ ) cocaine compared with those in the control (Fig. 4a). Furthermore, Rab11 expression was downregulated significantly in exosomes after exposure to $10 \mathrm{nM}$ (15\% decrease, $\mathrm{p} \leq 0.05), 100 \mathrm{nM}$ ( $28 \%$ decrease, $\mathrm{p} \leq 0.001)$, $1 \mu \mathrm{M}(25 \%$ decrease, $\mathrm{p} \leq 0.0001), 10 \mu \mathrm{M}$ (38\% decrease,

$\mathrm{p} \leq 0.0001)$ and $100 \mu \mathrm{M}(22 \%$ decrease, $\mathrm{p} \leq 0.0001)$ cocaine (Fig. 4b), Rab27A expression was significantly downregulated in exosomes after exposure to $100 \mathrm{nM}$ (21\% decrease, $\mathrm{p} \leq 0.05), 1 \mu \mathrm{M}(24 \%$ decrease, $\mathrm{p} \leq 0.001)$ and $100 \mu \mathrm{M}(23 \%$ decrease, $p \leq 0.001$ ) cocaine (Fig. $4 c$ ), and Rab35 expression had a slight increase at $10 \mathrm{nM}$ and $100 \mathrm{nM}$ and then a declining trend which was not statistically significant (Fig. 4d). This data suggests that Rab proteins may have a role in the reduction of exosome particles per $\mathrm{mL}$.

\section{Effects of Cocaine on the Lipid Components of Exosomes}

Lipids are a diverse group of molecules that consist of monoglycerides, diglycerides, triglycerides, fats, sterols, and others. Lipids not only play important roles in the maintenance 
A

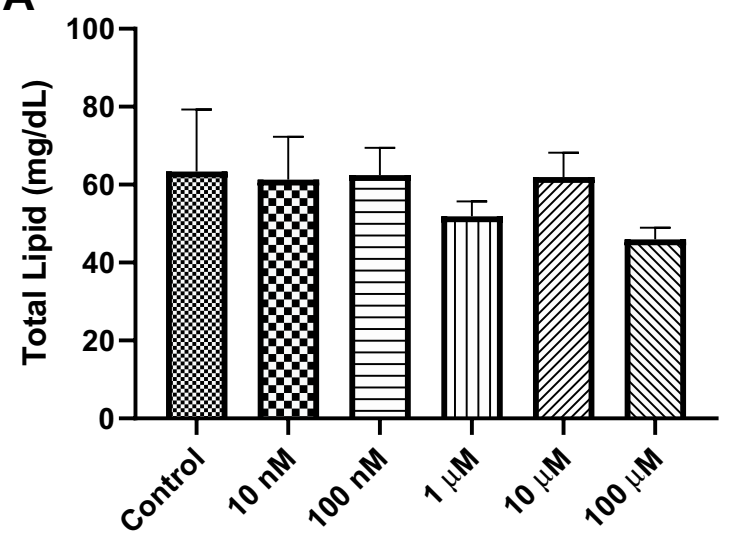

B

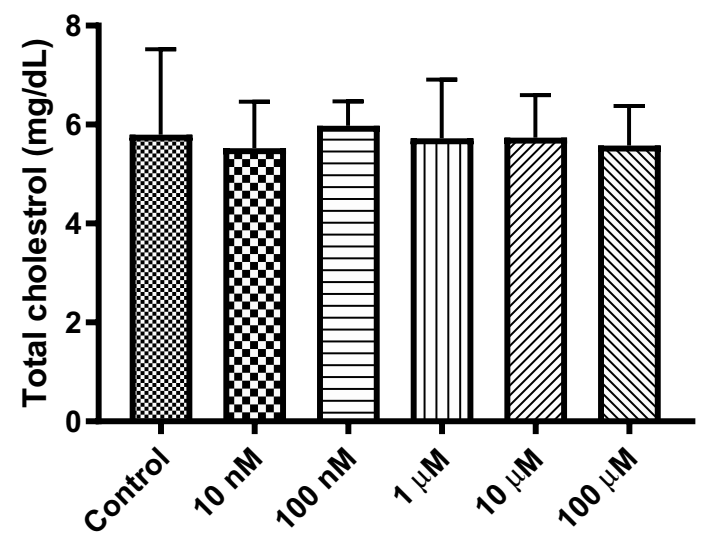

C

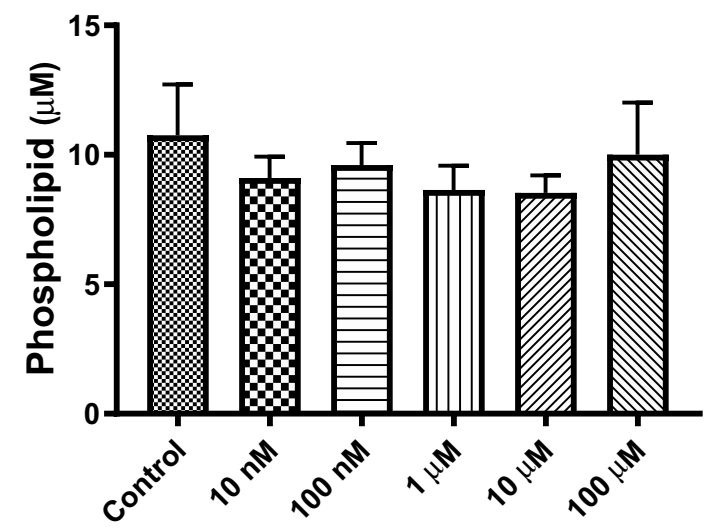

Fig. 5 Effects of cocaine on exosomal lipids. To examine the expression of various important lipids in exosomes, cells were exposed to various concentrations of cocaine for $24 \mathrm{~h}$, and lipid components were tested in exosomes. a total lipids, $\mathbf{b}$ total cholesterol, $\mathbf{c}$ phospho-

of cellular homeostasis and membrane integrity but also play significant roles in cellular communications, signaling, and apoptosis. To examine the distribution of lipids in exosomes, we performed fluorometric assays. Our data indicated that

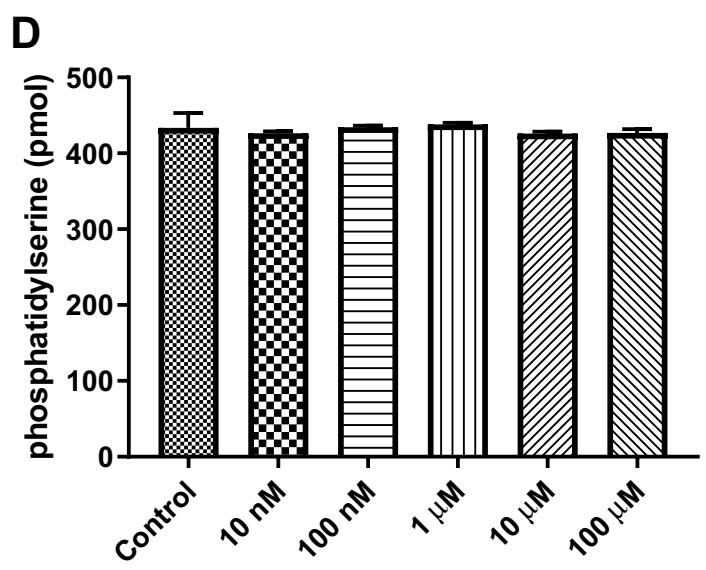

E

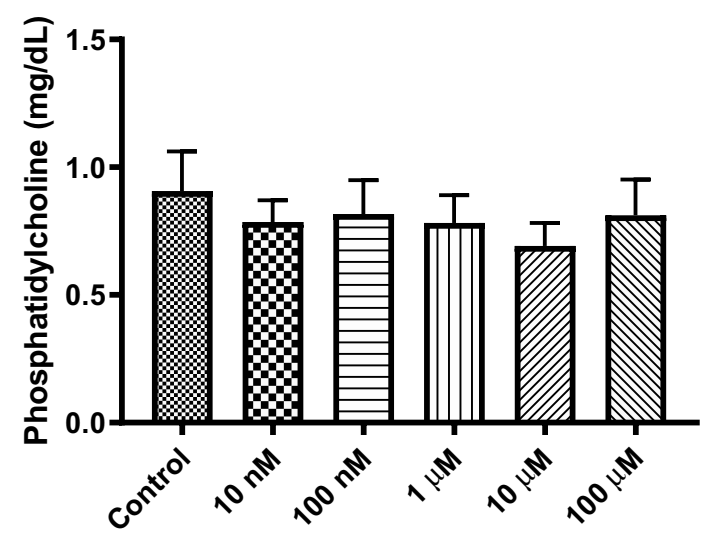

$\mathbf{F}$

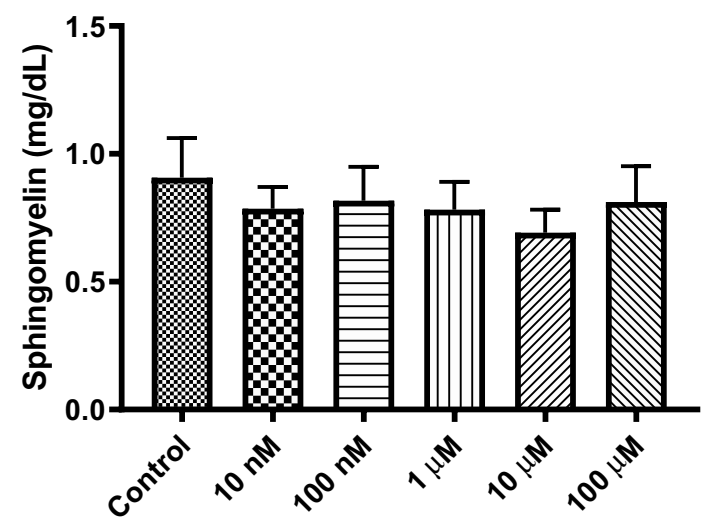

lipids, d phosphatidylserine, e phosphatidylcholine and f sphingomyelin were determined in exosomes by ELISA-based fluorometric assays. Graph showed the mean of SD derived from 5 independent experiment in triplicates

the expression levels of total lipids, phosphatidylcholine, phosphatidylserine, phospholipids, phosphatidylserine, sphingomyelin, and cholesterol were not significantly altered by exposure to cocaine (Fig. 5a-f). 


\section{Discussion}

Cocaine has been found to be associated with a variety of CNS disorders, such as the increased risk of stroke, seizures, cognitive impairments, depression, and, in extreme cases, death [48-50]. One plausible explanation for the many effects that cocaine has on the CNS may be the interruption of cell-to-cell communications and cell signaling, including those that involve microglial cells. Microglial cells are the most potent resident immune cells of the CNS and play a critical role in the surveillance of the brain environment [49, 51]. Although other studies have demonstrated that cocaine plays a role during endoplasmic reticulum stress, neuroinflammation, and Toll-like receptor-signaling, whether cocaine affects exosome biogenesis and composition has not been addressed until the current study. In previous studies, we examined the effects of another drug of abuse, alcohol, on exosome composition, and characteristics. Alcohol was found to have differential effects on the expression of several proteins in microglial cells [35], suggesting that other drugs of abuse could also affect microglial protein expression.

In the present investigation, we evaluated the cocainespecific effects on the biogenesis and composition of BV2 microglial cell-derived exosomes. Exosomes are nanosized vesicles that originate from the fusion of MVBs with the plasma membrane and are composed of proteins, lipids, mRNAs, and miRNAs. Exosomes play crucial roles in cellular communications, signaling, and the transportation of various molecules [52-55]. Recent research has addressed the roles played by exosomes in CNS-associated disorders (neurodegenerative, neurodevelopmental, and neuroinflammatory disorders) and immune regulation, and their roles as therapeutic vesicles [56-61]; however, whether cocainemediated alterations occur in exosomes (in the contexts of biogenesis and composition) is not yet understood. A study by Carone et. al, evaluated the effect of cocaine on tunneling nanotube formation and extracellular vesicle release in glioblastoma cell cultures [62]. This study used a range of cocaine concentrations to evaluate the effects of cocaine on tunneling nanotube formation and exosomes produced from glioblastoma cells. Our study herein, used a similar range of concentrations and time points that overlap this study. Our findings suggested that exposure for $24 \mathrm{~h}$ to $100 \mu \mathrm{M}$ cocaine significantly reduced the cell viability of BV2 microglial cells when compared with the control (Fig. 1a and b). Our findings also revealed that the mean size of exosomes after cocaine exposure remained unchanged (Fig. 1c and d), whereas the production of exosomes (particles per $\mathrm{mL}$ ) was markedly reduced after exposure to $100 \mathrm{nM}-10 \mu \mathrm{M}$ cocaine compared with the control (Fig. 1d).

Cell membrane proteins, such as CD63 and CD81, which are tetraspanin molecules, interact with a variety of cell surface markers and intracellular molecules and are involved in adhesion, motility, membrane organization, and signal transduction [35, 63]. Moreover, CD11b (a surface marker for microglia, monocytes, and macrophages) and CD18 are transmembrane proteins that play critical roles in cellular adhesion [64]. In this study, we showed that the expression of CD11b and CD18 were significantly upregulated in BV2 cells after exposure to $100 \mu \mathrm{M}$ cocaine (data not shown). These findings are in agreement with previous research that showed the increased expression of CD11b following nitric oxide exposure was associated with the activation of microglial cells during neurodegenerative inflammation [65]. A recent report has shown that disease-associated microglia express high levels of CD63, CD9, itgax, and Axl [66]. However, we found that CD63 did not demonstrate significant changes following cocaine exposure (Fig. 2). A significant downregulation was observed for CD81 expression after exposure to $100 \mathrm{~nm}, 1 \mu \mathrm{M}, 10 \mu \mathrm{M}$, and $100 \mu \mathrm{M}$ cocaine when compared with the control (data not shown). Furthermore, CD11b (Fig. 2b), CD18 (Fig. 2c), and CD63 (Fig. 2d) showed a slightly decreasing pattern of expression in exosomes, but these changes were not significant. CD81 was less expressed in microglial-derived exosomes (data not shown). These findings agreed with the previous studies and suggested that cocaine can impact the composition of exosomes.

Hsps are an evolutionarily conserved group of molecular chaperone proteins found in eukaryotes and prokaryotes and demonstrate protective functions under stress and trauma conditions, based on the upregulation of their expression levels under these conditions $[67,68]$. Levandowski et al, in 2016, showed that cocaine addiction exerted stress during early life and accelerated the cellular aging process among women [69]. Our findings demonstrated that the expression levels of Hsp70 (Fig. 3a) and Hsp90 (Fig. 3b) have upregulated in BV2 cell-derived exosomes, suggesting that cocaine exerts stress on BV2 cells, which can further modulate exosome biogenesis and composition.

Rab proteins are well-known members of the Ras superfamily of small Rab GTPases, which play important roles during exosome biogenesis and secretion [46, 70]. Rab5 and Rab7 can be found in the plasma membrane and early endosomes and are associated with controlled trafficking, whereas Rab11, Rab27A, and Rab35 contribute to the sorting, secretion, and transportation of exosomes. Previous reports have indicated that Rab5 regulates the early endocytic pathway, can be found on clathrin-coated vesicles, and regulates endosomal trafficking [45, 47]. Rab7 is an important regulatory component of the endosome-to-lysosome pathway [47]; however, the present findings suggested that Rab7 expression was upregulated in exosomes after cocaine exposure (Fig. 4a), suggesting that it may be involved in directing exosomes toward the lysosomal degradation 
pathway, resulting in a decrease in the number of particles per $\mathrm{mL}$. Each Rab protein has a specific subcellular localization and a different function; however, only Rab11, Rab27, and Rab35 are known to regulate exosome release/secretion [71]. We showed that Rab11 (Fig. 4b) and Rab27 (Fig. 4c) expression in exosomes were significantly suppressed compared with their respective controls (Fig. 4). These findings suggested that the downregulation of Rab protein expression might be associated with reduced exosome release into the extracellular environment; therefore, the observed decrease in exosome particles per $\mathrm{mL}$ can be correlated with the current findings (Fig. 1e). Since Rab proteins are implemented in multiple aspects of disease progression, they might represent new therapeutic targets in controlling disease progression [72]. Although Rab-specific drugs have not been available for public use, it is important to add findings that exposure to cocaine may regulate Rab proteins. Rab-specific modulation has already been reviewed by Qin et al. demonstrated the use of nucleotide based competitive inhibitors that target kinases, blocking protein-protein interactions, and small interfering RNA such as siRNA and miRNA [73].

Lipids are the most important components of the plasma membrane and play important roles in cellular homeostasis, membrane integrity, cellular communications, signaling, and apoptosis. Studies have demonstrated that exosomes are enriched in lipids compared with their parent cells, and we hypothesized that drugs of abuse, such as cocaine, may affect the lipid composition of exosomes [74-76]; however, our results indicated that the expression levels of total lipids, phosphatidylcholine, phosphatidylserine, phospholipids, phosphatidylserine, sphingomyelin, and cholesterol remained unchanged during exosome production and secretion after cocaine exposure (Fig. 5). One caveat to our findings may be the limited range of sensitivity of our detection system. Further lipid analysis might be warranted with an assay that has a greater sensitivity (i.e. gas chromatographymass spectrometry).

The strength of this study is that it adds to the body of literature concerning the effect of cocaine on exosome production in microglial cells. To our knowledge this is the first study of its kind to evaluate measures such as microglia cell viability after cocaine treatment, exosome size, exosome quantity, and composition (i.e. protein and lipid quantity/ profile). Although, one limitation of our work is that our work cannot be compared directly to Carone et al. [62], because the experimental design differs. However, some of our findings concerning the effects of cocaine on total exosomes numbers after time show opposite results on Carone's study, indicated that the effect of cocaine and exosome regulation may be cell-type specific. In our study, we focused on the effect of cocaine on proteins and lipids directly and did not look at the effect of microRNA. Cocaine could plausibly effect microRNA content and will be the focus of future work.

\section{Conclusions}

In summary, our findings provide insight into cocainespecific effects on BV2 cell-derived exosome biogenesis and composition. In brief, our findings demonstrated that high concentrations of cocaine exposure reduced the cell survival of microglial BV2 cells and disturbed exosome biogenesis and composition by modulating the expression levels of Rab GTPases and membrane proteins, such as CD molecules, Hsps, and signaling molecules; however, the lipid components in exosomes remained unchanged after cocaine exposure. Specifically, increasing Rab7 expression could lead to increase clearance of exosomes via lysosomes and a concomitant decrease in exosome production by regulating Rab11 and Rab27. Therefore, our findings suggested that cocaine can have dramatic effects on exosome biogenesis and composition; however, further investigation is warranted to explore the specific underlying mechanism(s).

Supplementary Information The online version of this article (doi:https://doi.org/10.1007/s11064-021-03231-2) contains supplementary material, which is available to authorized users.

Acknowledgments We are thankful to the High-Resolution Imaging Facility Service Center, who provided NTA. The High-Resolution Imaging Facility is an institutional core at the University of Alabama at Birmingham supported by the Office of the Vice President of Research and development and the following Grants: Cancer Center Support Grant P30 CA013148 Rheumatic Disease Core Center P30 AR048311.

Author contributions Formal analysis, BS; Funding acquisition, QLM; Investigation, SK, BJC, SW, QLM and BS; Methodology, SK, BJC, SW and QLM; Supervision, BS; Writing-original draft, BJC, SK and BS; Writing—review \& editing, BS.

Funding This work was funded by the National Institutes of Health, \# 1R15DA045564-01 and \# 5R25MH080661-13/2004445114, and National Science Foundation Grant, \# No 1900377.

Open Access This article is licensed under a Creative Commons Attribution 4.0 International License, which permits use, sharing, adaptation, distribution and reproduction in any medium or format, as long as you give appropriate credit to the original author(s) and the source, provide a link to the Creative Commons licence, and indicate if changes were made. The images or other third party material in this article are included in the article's Creative Commons licence, unless indicated otherwise in a credit line to the material. If material is not included in the article's Creative Commons licence and your intended use is not permitted by statutory regulation or exceeds the permitted use, you will need to obtain permission directly from the copyright holder. To view a copy of this licence, visit http://creativecommons.org/licenses/by/4.0/. 


\section{References}

1. Kreutzberg GW (1996) Microglia: a sensor for pathological events in the CNS. Trends Neurosci 19:312-318

2. Dickson DW, Lee SC (1996) Microglia in HIV-related CNS neuropathology: an update. J NeuroAIDS 1:57-83

3. Gehrmann J, Banati RB (1995) Microglial turnover in the injured CNS: activated microglia undergo delayed DNA fragmentation following peripheral nerve injury. J Neuropathol Exp Neurol 54:680-688

4. Thompson KK, Tsirka SE (2017) The diverse roles of microglia in the neurodegenerative aspects of central nervous system (CNS) autoimmunity. Int J Mol Sci 18:504

5. Tsuda M (2018) Microglia in the CNS and neuropathic pain. Adv Exp Med Biol 1099:77-91

6. Glebov K, Lochner M, Jabs R, Lau T, Merkel O, Schloss P, Steinhauser C, Walter J (2015) Serotonin stimulates secretion of exosomes from microglia cells. Glia 63:626-634

7. Zhou J, Li X, Wu X, Zhang T, Zhu Q, Wang X, Wang H, Wang $\mathrm{K}$, Lin Y, Wang X (2018) Exosomes released from tumor-associated macrophages transfer miRNAs that induce a Treg/Th17 cell imbalance in epithelial ovarian cancer. Cancer Immunol Res 6:1578-1592

8. Zoller M (2018) Janus-faced myeloid-derived suppressor cell exosomes for the good and the bad in cancer and autoimmune disease. Front Immunol 9:137

9. Li Z, Liu F, He X, Yang X, Shan F, Feng J (2019) Exosomes derived from mesenchymal stem cells attenuate inflammation and demyelination of the central nervous system in EAE rats by regulating the polarization of microglia. Int Immunopharmacol 67:268-280

10. Potolicchio I, Carven GJ, Xu X, Stipp C, Riese RJ, Stern LJ, Santambrogio L (2005) Proteomic analysis of microglia-derived exosomes: metabolic role of the aminopeptidase CD13 in neuropeptide catabolism. J Immunol 175:2237-2243

11. Thomi G, Surbek D, Haesler V, Joerger-Messerli M, Schoeberlein A (2019) Exosomes derived from umbilical cord mesenchymal stem cells reduce microglia-mediated neuroinflammation in perinatal brain injury. Stem Cell Res Ther 10:105

12. Jalabert A, Vial G, Guay C, Wiklander OP, Nordin JZ, Aswad H, Forterre A, Meugnier E, Pesenti S, Regazzi R, Danty-Berger E, Ducreux S, Vidal H, El-Andaloussi S, Rieusset J, Rome S (2016) Exosome-like vesicles released from lipid-induced insulin-resistant muscles modulate gene expression and proliferation of beta recipient cells in mice. Diabetologia 59:1049-1058

13. Skotland T, Hessvik NP, Sandvig K, Llorente A (2019) Exosomal lipid composition and the role of ether lipids and phosphoinositides in exosome biology. J Lipid Res 60:9-18

14. Subra C, Laulagnier K, Perret B, Record M (2007) Exosome lipidomics unravels lipid sorting at the level of multivesicular bodies. Biochimie 89:205-212

15. Svensson KJ, Christianson HC, Wittrup A, Bourseau-Guilmain E, Lindqvist E, Svensson LM, Morgelin M, Belting M (2013) Exosome uptake depends on ERK1/2-heat shock protein 27 signaling and lipid Raft-mediated endocytosis negatively regulated by caveolin-1. J Biol Chem 288:17713-17724

16. de Gassart A, Geminard C, Fevrier B, Raposo G, Vidal M (2003) Lipid raft-associated protein sorting in exosomes. Blood 102:4336-4344

17. Deng H, Sun C, Sun Y, Li H, Yang L, Wu D, Gao Q, Jiang X (2018) Lipid, protein, and microRNA composition within mesenchymal stem cell-derived exosomes. Cell Reprogram 20:178-186

18. Kastelowitz N, Yin H (2014) Exosomes and microvesicles: identification and targeting by particle size and lipid chemical probes. ChemBioChem 15:923-928
19. Sano S, Izumi Y, Yamaguchi T, Yamazaki T, Tanaka M, Shiota M, Osada-Oka M, Nakamura Y, Wei M, Wanibuchi H, Iwao H, Yoshiyama M (2014) Lipid synthesis is promoted by hypoxic adipocyte-derived exosomes in 3T3-L1 cells. Biochem Biophys Res Commun 445:327-333

20. Skotland T, Ekroos K, Kauhanen D, Simolin H, Seierstad T, Berge V, Sandvig K, Llorente A (2017) Molecular lipid species in urinary exosomes as potential prostate cancer biomarkers. Eur J Cancer 70:122-132

21. van Niel G, Porto-Carreiro I, Simoes S, Raposo G (2006) Exosomes: a common pathway for a specialized function. J Biochem 140:13-21

22. Cotto B, Li H, Tuma RF, Ward SJ, Langford D (2018) Cocainemediated activation of microglia and microglial MeCP2 and BDNF production. Neurobiol Dis 117:28-41

23. Dhillon NK, Peng F, Bokhari S, Callen S, Shin SH, Zhu X, Kim KJ, Buch SJ (2008) Cocaine-mediated alteration in tight junction protein expression and modulation of CCL2/CCR2 axis across the blood-brain barrier: implications for HIV-dementia. J Neuroimmune Pharmacol 3:52-56

24. Kolodgie FD, Wilson PS, Mergner WJ, Virmani R (1999) Cocaine-induced increase in the permeability function of human vascular endothelial cell monolayers. Exp Mol Pathol 66:109-122

25. Sharma HS, Muresanu D, Sharma A, Patnaik R (2009) Cocaineinduced breakdown of the blood-brain barrier and neurotoxicity. Int Rev Neurobiol 88:297-334

26. Yao H, Duan M, Buch S (2011) Cocaine-mediated induction of platelet-derived growth factor: implication for increased vascular permeability. Blood 117:2538-2547

27. Mahoney JJ (2018) Cognitive dysfunction in individuals with cocaine use disorder: potential moderating factors and pharmacological treatments. Exp Clin Psychopharmacol 27:203-214

28. Moeller SJ, Zilverstand A, Konova AB, Kundu P, Parvaz MA, Preston-Campbell R, Bachi K, Alia-Klein N, Goldstein RZ (2018) Neural correlates of drug-biased choice in currently using and abstinent individuals with cocaine use disorder. Biol Psychiatry Cogn Neurosci Neuroimaging 3:485-494

29. Gekker G, Hu S, Sheng WS, Rock RB, Lokensgard JR, Peterson PK (2006) Cocaine-induced HIV-1 expression in microglia involves sigma-1 receptors and transforming growth factor-beta1. Int Immunopharmacol 6:1029-1033

30. Periyasamy P, Liao K, Kook YH, Niu F, Callen SE, Guo ML, Buch S (2018) Cocaine-mediated downregulation of miR-124 activates microglia by targeting KLF4 and TLR4 signaling. Mol Neurobiol 55:3196-3210

31. Biber K, Neumann H, Inoue K, Boddeke HW (2007) Neuronal "On" and "Off" signals control microglia. Trends Neurosci 30:596-602

32. Fong R, Kissmeyer-Nielsen F (1972) A combined dye exclusion (trypan blue) and fluorochromatic technique for the microdroplet lymphocytotoxicity test. Tissue Antigens 2:57-63

33. Hathaway WE, Newby LA, Githens JH (1964) The acridine orange viability test applied to bone marrow cells. I. Correlation with trypan blue and eosin dye exclusion and tissue culture transformation. Blood 23:517-525

34. Strober W (2015) Trypan blue exclusion test of cell viability. Curr Protoc Immunol 111:1-3

35. Crenshaw BJ, Kumar S, Bell CR, Jones LB, Williams SD, Saldanha SN, Joshi S, Sahu R, Sims B, Matthews QL (2019) Alcohol modulates the biogenesis and composition of microgliaderived exosomes. Biology (Basel) 8:25

36. Sims B, Gu L, Krendelchtchikov A, Matthews QL (2014) Neural stem cell-derived exosomes mediate viral entry. Int J Nanomedicine 9:4893-4897 
37. Parthasarathy V, Martin F, Higginbottom A, Murray H, Moseley GW, Read RC, Mal G, Hulme R, Monk PN, Partridge LJ (2009) Distinct roles for tetraspanins CD9, CD63 and CD81 in the formation of multinucleated giant cells. Immunology 127:237-248

38. Radford KJ, Thorne RF, Hersey P (1996) CD63 associates with transmembrane 4 superfamily members, CD9 and CD81, and with beta 1 integrins in human melanoma. Biochem Biophys Res Commun 222:13-18

39. Rubinstein E, Le Naour F, Lagaudriere-Gesbert C, Billard M, Conjeaud H, Boucheix C (1996) CD9, CD63, CD81, and CD82 are components of a surface tetraspan network connected to HLADR and VLA integrins. Eur J Immunol 26:2657-2665

40. Seldin MF, Rochelle JM, Tomlinson MG, Wright MD (1995) Mapping of the genes for four members of the transmembrane 4 superfamily: mouse $\mathrm{Cd} 9, \mathrm{Cd} 63$, Cd81, and Cd82. Immunogenetics 42:422-425

41. Tippett E, Cameron PU, Marsh M, Crowe SM (2013) Characterization of tetraspanins CD9, CD53, CD63, and CD81 in monocytes and macrophages in HIV-1 infection. J Leukoc Biol 93:913-920

42. Hyun YM, Choe YH, Park SA, Kim M (2019) LFA-1 (CD11a/ CD18) and Mac-1 (CD11b/CD18) distinctly regulate neutrophil extravasation through hotspots I and II. Exp Mol Med 51:39

43. Kumar S, Gurshaney S, Adagunodo Y, Gage E, Qadri S, Sharma M, Malik S, Manne U, Singh UP, Singh R, Mishra MK (2018) Hsp70 and gama-semino protein as possible prognostic marker of prostate cancer. Front Biosci (Landmark Ed) 23:1987-2000

44. Kumar S, Stokes J 3rd, Singh UP, Scissum Gunn K, Acharya A, Manne U, Mishra M (2016) Targeting Hsp70: a possible therapy for cancer. Cancer Lett 374:156-166

45. Hutagalung AH, Novick PJ (2011) Role of Rab GTPases in membrane traffic and cell physiology. Physiol Rev 91:119-149

46. Dorayappan KDP, Wanner R, Wallbillich JJ, Saini U, Zingarelli R, Suarez AA, Cohn DE, Selvendiran K (2018) Hypoxia-induced exosomes contribute to a more aggressive and chemoresistant ovarian cancer phenotype: a novel mechanism linking STAT3/ Rab proteins. Oncogene 37:3806-3821

47. Fouraux MA, Deneka M, Ivan V, van der Heijden A, Raymackers J, van Suylekom D, van Venrooij WJ, van der Sluijs P, Pruijn GJ (2004) Rabip4' is an effector of rab5 and rab4 and regulates transport through early endosomes. Mol Biol Cell 15:611-624

48. Gold MS, Dackis CA, Pottash AL, Extein I, Washton A (1985) Cocaine update: from bench to bedside. Adv Alcohol Subst Abuse 5:35-60

49. Spear LP, Kirstein CL, Frambes NA (1989) Cocaine effects on the developing central nervous system: behavioral, psychopharmacological, and neurochemical studies. Ann N Y Acad Sci 562:290-307

50. DiGregorio GJ (1990) Cocaine update: abuse and therapy. Am Fam Physician 41:247-250

51. Henn A, Lund S, Hedtjarn M, Schrattenholz A, Porzgen P, Leist M (2009) The suitability of BV2 cells as alternative model system for primary microglia cultures or for animal experiments examining brain inflammation. Altex 26:83-94

52. Clayton A, Turkes A, Dewitt S, Steadman R, Mason MD, Hallett MB (2004) Adhesion and signaling by B cell-derived exosomes: the role of integrins. FASEB J 18:977-979

53. Gernapudi R, Yao Y, Zhang Y, Wolfson B, Roy S, Duru N, Eades G, Yang P, Zhou Q (2015) Targeting exosomes from preadipocytes inhibits preadipocyte to cancer stem cell signaling in earlystage breast cancer. Breast Cancer Res Treat 150:685-695

54. Kourembanas S (2015) Exosomes: vehicles of intercellular signaling, biomarkers, and vectors of cell therapy. Annu Rev Physiol 77:13-27

55. Lin R, Wang S, Zhao RC (2013) Exosomes from human adiposederived mesenchymal stem cells promote migration through Wnt signaling pathway in a breast cancer cell model. Mol Cell Biochem 383:13-20

56. Paschon V, Takada SH, Ikebara JM, Sousa E, Raeisossadati R, Ulrich H, Kihara AH (2016) Interplay between exosomes, microRNAs and toll-like receptors in brain disorders. Mol Neurobiol 53:2016-2028

57. Perets N, Betzer O, Shapira R, Brenstein S, Angel A, Sadan T, Ashery U, Popovtzer R, Offen D (2019) Golden exosomes selectively target brain pathologies in neurodegenerative and neurodevelopmental disorders. Nano Lett 19:3422-3431

58. Shen Y, Xue C, Li X, Ba L, Gu J, Sun Z, Han Q, Zhao RC (2019) Effects of gastric cancer cell-derived exosomes on the immune regulation of mesenchymal stem cells by the NF-kB signaling pathway. Stem Cells Dev 28:464-476

59. Wang S, Su X, Xu M, Xiao X, Li X, Li H, Keating A, Zhao RC (2019) Exosomes secreted by mesenchymal stromal/stem cellderived adipocytes promote breast cancer cell growth via activation of Hippo signaling pathway. Stem Cell Res Ther 10:117

60. Zhang W, Bai X, Zhao B, Li Y, Zhang Y, Li Z, Wang X, Luo L, Han F, Zhang J, Han S, Cai W, Su L, Tao K, Shi J, Hu D (2018) Cell-free therapy based on adipose tissue stem cell-derived exosomes promotes wound healing via the PI3K/Akt signaling pathway. Exp Cell Res 370:333-342

61. Zhu B, Zhang L, Liang C, Liu B, Pan X, Wang Y, Zhang Y, Zhang Y, Xie W, Yan B, Liu F, Yip HK, Yu XY, Li Y (2019) Stem cell-derived exosomes prevent aging-induced cardiac dysfunction through a novel exosome/lncRNA MALAT1/NF-kappaB/TNFalpha signaling pathway. Oxid Med Cell Longev 2019:9739258

62. Carone C, Genedani S, Leo G, Filaferro M, Fuxe K, Agnati LF (2015) In vitro effects of cocaine on tunneling nanotube formation and extracellular vesicle release in glioblastoma cell cultures. J Mol Neurosci 55:42-50

63. Jeong HK, Ji K, Min K, Joe EH (2013) Brain inflammation and microglia: facts and misconceptions. Exp Neurobiol 22:59-67

64. Choucair-Jaafar N, Laporte V, Levy R, Poindron P, Lombard Y, Gies JP (2011) Complement receptor 3 (CD11b/CD18) is implicated in the elimination of beta-amyloid peptides. Fundam Clin Pharmacol 25:115-122

65. Roy A, Fung YK, Liu X, Pahan K (2006) Up-regulation of microglial CD11b expression by nitric oxide. J Biol Chem 281:14971-14980

66. Mathys H, Adaikkan C, Gao F, Young JZ, Manet E, Hemberg M, De Jager PL, Ransohoff RM, Regev A, Tsai LH (2017) Temporal tracking of microglia activation in neurodegeneration at singlecell resolution. Cell Rep 21:366-380

67. Kakimura J, Kitamura Y, Takata K, Umeki M, Suzuki S, Shibagaki K, Taniguchi T, Nomura Y, Gebicke-Haerter PJ, Smith MA, Perry G, Shimohama S (2002) Microglial activation and amyloidbeta clearance induced by exogenous heat-shock proteins. FASEB J 16:601-603

68. Gulke E, Gelderblom M, Magnus T (2018) Danger signals in stroke and their role on microglia activation after ischemia. Ther Adv Neurol Disord 11:1756286418774254

69. Levandowski ML, Tractenberg SG, de Azeredo LA, De Nardi T, Rovaris DL, Bau CH, Rizzo LB, Maurya PK, Brietzke E, Tyrka AR, Grassi-Oliveira R (2016) Crack cocaine addiction, early life stress and accelerated cellular aging among women. Prog Neuropsychopharmacol Biol Psychiatry 71:83-89

70. Xiao D, Barry S, Kmetz D, Egger M, Pan J, Rai SN, Qu J, McMasters KM, Hao H (2016) Melanoma cell-derived exosomes promote epithelial-mesenchymal transition in primary melanocytes through paracrine/autocrine signaling in the tumor microenvironment. Cancer Lett 376:318-327

71. Colombo M, Raposo G, Thery C (2014) Biogenesis, secretion, and intercellular interactions of exosomes and other extracellular vesicles. Annu Rev Cell Dev Biol 30:255-289 
72. Recchi C, Seabra MC (2012) Novel functions for Rab GTPases in multiple aspects of tumour progression. Biochem Soc Trans 40:1398-1403

73. Qin X, Wang J, Wang X, Liu F, Jiang B, Zhang Y (2017) Targeting Rabs as a novel therapeutic strategy for cancer therapy. Drug Discov Today 22:1139-1147

74. Kojima M, Gimenes-Junior JA, Langness S, Morishita K, LavoieGagne O, Eliceiri B, Costantini TW, Coimbra R (2017) Exosomes, not protein or lipids, in mesenteric lymph activate inflammation: unlocking the mystery of post-shock multiple organ failure. J Trauma Acute Care Surg 82:42-50
75. Nakase I, Futaki S (2015) Combined treatment with a pH-sensitive fusogenic peptide and cationic lipids achieves enhanced cytosolic delivery of exosomes. Sci Rep 5:10112

76. Skotland T, Sandvig K, Llorente A (2017) Lipids in exosomes: current knowledge and the way forward. Prog Lipid Res 66:30-41

Publisher's Note Springer Nature remains neutral with regard to jurisdictional claims in published maps and institutional affiliations. 